\title{
Phytodetritus at the sediment-water interface, NW Mediterranean Basin: spatial repartition, living cells signatures, meiofaunal relationships*
}

\author{
CATHERINE RIAUX-GOBIN ${ }^{1}$, ALAIN DINET $^{1}$, GRÉGORY DUGUÉ $^{2}$, GILLES VÉTION $^{1}$, \\ ERIC MARIA $^{1}$ and ANTOINE GRÉMARE ${ }^{1}$ \\ ${ }^{1}$ UMR CNRS 7621, Laboratoire Arago B.P. 44, 66651, Banyuls/mer Cédex, France. E-mail: riaux-go@obs-banyuls.fr \\ 2 , rue des Saulx, 28130, St Martin de Nigelles, France.
}

\begin{abstract}
SUMMARY: The deep-sea phytodetritus at the sediment-water interface was investigated in the continental margin, canyons and interfluves from 260 to $2070 \mathrm{~m}$ depth in the northwestern Mediterranean in June 1995. Overlying phytoplankton biomass, hydrodynamics and relationships with meiofauna densities were also evaluated. The phytoplankton biomass was low $\left(<0.2 \mu \mathrm{g} \mathrm{Chl} a \mathrm{l}^{-1}\right)$, with the lowest standing stocks on the eastern part of the Balearic Basin. Two sedimentary

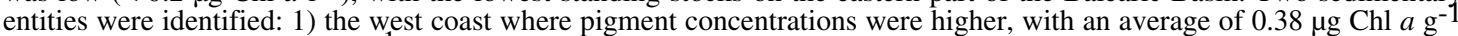
dry weight and 4.60 Phaeo $a \mathrm{~g}^{-1} \mathrm{dw}$ on the first half $\mathrm{cm}$ of sediments; and 2) the eastern part of the North Balearic basin where pigment concentrations were significantly lower $\left(0.15 \mu \mathrm{g} \mathrm{Chl} a \mathrm{~g}^{-1} \mathrm{dw}\right)$. A north to south gradient was observed, with higher pigment amounts on the Rhodanian slope. Differences were found in the different parts of the studied canyons, with a slight increase in the Axis sites. The vertical pigment repartition was a gradual decrease in the Interfluve sites, whereas concentrations decreased sharply below the first $\mathrm{cm}$ in the Axis sites, attesting differences in sedimentation, grazing or bioturbation within the different canyon parts. The north to south gradient in the phytoplankton $\mathrm{Chl} a / \mathrm{Chl} b$ ratio and sedimented phytodetritus attest geographical differences within phytoplankton assemblages (i.e. diatoms are absent in the south). The epifluorescence tests from the interface revealed the presence of living microphytes at the northern sites, associated with aggregates and faeces. No consistent fluff was evidenced anywhere. The revival tests also agree with a north to south trend. The Meiofaunal density was positively related to the quality of the sedimented layer. A PCA, within the major parameters and factors, illustrates these relationships. All results allow two distinct geographical sectors to be discriminated around the frontal zone: the NW and E sides of the NW Mediterranean Basin, following in particular their contrasted hydrodynamics. The results indicated the relationships within phytoplankton input, underlying phytodetritic layer and meiofauna. They confirm the well-documented statement that demonstrates the deep-sea floor chloropigment concentration to be a good proxy for the overlying primary productivity, but also that some pigment ratios representative of plankton assemblages are preserved on surficial deep sediments, even after sedimentation and grazing.
\end{abstract}

Key-words: deep-sea phytodetritus, meiofauna, phytoplankton, NW Mediterranean Basin.

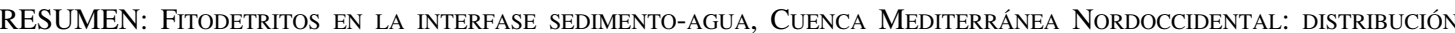
ESPACIAL, SEÑALES DE CÉLULAS VIVAS, RELACIONES CON LA MEIOFAUNA. - Se investigó el detrito de agua profunda en la interface sedimento-agua en el margen continental, caniones y interfluves entre 260 y $2070 \mathrm{~m}$ de profundidad en el mar Mediterráneo Noroccidental en junio de 1995. La biomasa de fitoplancton flotante, la hidrodinámica, y las relaciones con las densidades de meiofauna fueron también evaluadas. La biomassa de fitotoplancton fue baja $\left(<0.2 \mu \mathrm{g} \mathrm{Chl} a 1^{-1}\right)$, con los standing stocks mas bajos en la parte oriental de la cuenca Balear. Dos entidades sedimentarias fueron identificadas: 1) la costa occidental donde las concentraciones de pigmento fueron mas altas: $0.38 \mu \mathrm{g} \mathrm{Chl} a \mathrm{~g}^{-1}$ peso seco (ps) en promedio y 4.60 Phaeo $a \mathrm{~g}^{-1}$ ps en el 0,5 cm de sedimento, y 2) la parte oriental de la cuenca Balear Norte donde las concentraciones de pigmentos fueron significativamente mas bajas $\left(0.15 \mu \mathrm{g} \mathrm{Chl} a \mathrm{~g}^{-1} \mathrm{ps}\right)$. Se reconoció un gradiente norte-sur, con valores mas altos de pigmentos en la pendiente Rodaniana. Fueron observadas diferencias en las distintas partes de los cañones estudiados, con un incremente menor en "Eje". La distribución vertical de pigmentos mostró una disminución gradual en los esta- 
ciones de "Interfluve", mientras que las concentraciones decrecieron fuertemente debajo del primer centímetro en las posiciones del "Eje", corroborando diferencias en sedimentación, grazing o bioturbación dentro de las diferentes partes del cañón. El gradiente norte-sur en la relación de $\mathrm{Chl} a / \mathrm{Chl} b$ de fitoplancton y los fitodetritos sedimentados muestran diferencias geográficas dentro de las asociaciones fitoplanctónicas (i.e. diatomeas están ausentes en el sur). Los tests de epifluorescencia en la interfase revelaron la presencia de microfitas vivientes en los estaciones del norte, asociados con agregados y faeces. Evidencia de un "fluff" consistente no fue encontrada. Los tests de "revival" también coinciden con una tendencia norte-sud. La densidad de meiofauna se relaciona positivamente con la cualidad de la capa sedimentada. Un análisis de componentes principales, con los mayores parámetros y factores, ilustra estas relaciones. Todos los resultados permiten discriminar dos sectores geográficos bien distintos cerca de la zona frontal: los lados NW y E de la cuenca Mediterránea NW siguiendo, en particular, sus contrastantes hidrodinámicas. Los resultados muestran las relaciones dentro del input de fitoplancton, yaciendo debajo de la capa fitodetrítica y la meiofauna. Esto confirma la afirmación que la concentración de cloropigmentos en el fondo del océano profundo es un buen indicador de la productividad primaria en aguas superiores, y también que algunos ratios de pigmentos, representativos de asociaciones planctónicas, son preservados en sedimentos superficiales profundos, aun después de la sedimentación

Palabras clave: fitodetritos de océano profundo, meiofauna, fitoplancton, Cuenca Mediterránea noroccidental.

\section{INTRODUCTION}

In the last decade several studies have pointed out the complexity of Mediterranean hydrology, the specificity of each basin and the level of productivity. This productivity is not so dramatically low and uniform as previously reported (Barlow et al., 1997). In the northwestern Mediterranean basin (Gulf of Lions and Catalan Sea) the hydrodynamics and associated phytoplankton features have been widely investigated (Estrada, 1985; Margalef, 1985; Estrada and Margalef, 1988; Masó and Duarte, 1989). Whereas the phytoplankton biomass is often described as low in surface Mediterranean waters, it can reach up to $2 \mu \mathrm{g}^{-1}$ in the deep chlorophyll maximum (DCM), more or less linked to the dome (Estrada, 1985), and also up to $2 \mu \mathrm{g}^{-1}$ in off-shore surface waters near the Catalan front (Estrada and Margalef, 1988). The more or less stable DCM can generate not only POC sedimentation, but also short-term events in surficial water masses. This may have been neglected in the past. These pulse blooms near the fronts may generate enriched nearbottom deep layers. As a probable result of such events, brownish fluffs on the deep-sea sediment surface were sampled in the Gulf of Lions in MarchApril 1991 (1584 m, 42²1N- $3^{\circ} 55 \mathrm{E}, 10^{5} \mathrm{l}^{-1}$ encysted microphytes, mainly Chaetoceros sp; RiauxGobin and Descolas-Gros, 1992; Riaux-Gobin et al., 1995). Mass sedimentation events may be spatially restricted and escape conventional investigations, whereas the sedimented material may reflect these events: still living cells or encysted cells on the surface of deep sediments may be their fingerprints.

The biochemical characterization of phytodetritus at the water-sediment interface, and its level of preservation or transformation, may provide information on its origin and sedimentation features
(Santos et al., 1994; Riaux-Gobin et al., 1997; Beaulieu and Smith, 1998). Spring blooms, upwelling areas or frontal zones favour such fast or "in pulse" plankton sedimentation, which may generate enriched deep layers (cf. refs. in Cushing, 1992). In temperate areas bio-deposition to the deep-sea floor has been demonstrated to be pulsing with pronounced inter-annual variability (Lampitt, 1985; Rice et al., 1986; Thiel et al., 1988-89), and to be linked to productive frontal zones. Furthermore, degraded or intact phytoplankton reaching the deepsea floor may be an important nutritional source for benthic heterotrophs (Billet et al., 1983; Thiel et al., 1988-89; Lochte and Turley, 1988; Pfannkuche et al., 1999; Pfannkuche et al., 2000).

In the NW Mediterranean margin and deep-sea floor, sedimentation processes, by way of trap deposition and/or sediment accumulation, were studied at different time-scales: the Holocene scale $(10,000$ years) by Got and Aloisi (1990) and the annual/seasonal scale by Monaco et al. (1990) and Puig and Palanques (1998). Radionuclides, mainly ${ }^{210} \mathrm{~Pb}$ fluxes, have been successfully used by Heussner et al. (1990), and recently by Zuo et al. (1997), who give revised rates and a spatial distribution of these annual sedimentation rates corresponding to the present study area (Zuo et al., 1997).

The river contribution dominates the deposition system. The Rhone influence in the Gulf of Lions sedimentation (Thomas, 1997) is important, but more or less restricted to the pro-delta and showing a low incidence on the abyssal plain: off-shore sedimentation originates in atmospheric input and oceanic productivity. More or less the same conclusions are given by Bouloubassi et al. (1990), using organic markers, about the Ebro impact.

Biological implications of these sedimented layers, such as the relationships with benthic meiofau- 


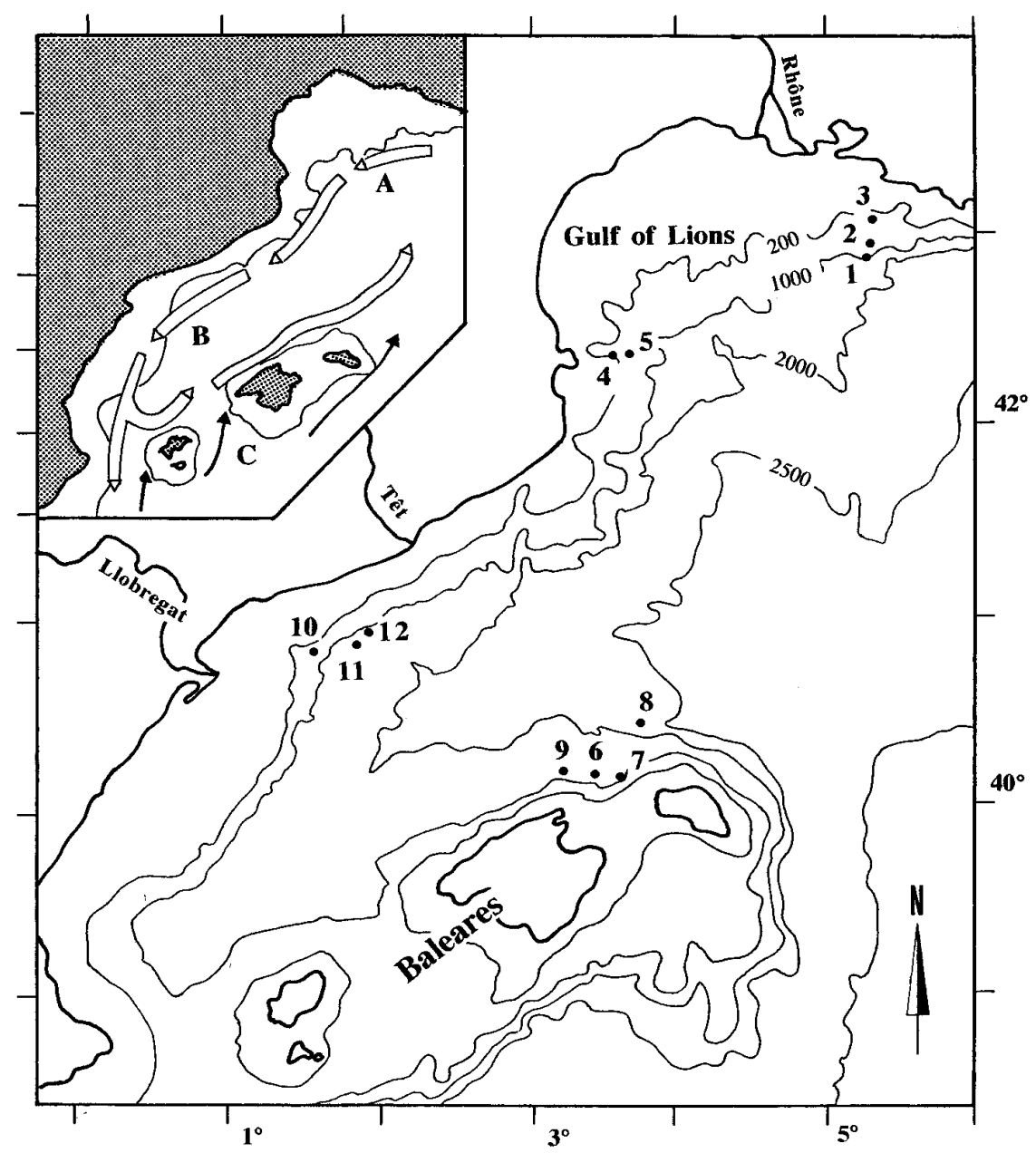

FIG. 1. - Location of the sampling sites in the Gulf of Lions, the Foix canyon and the Balearic Islands sites (cf. Table 1); also indicated are circulation features of interest, including the Liguro-Provençal drift (A), the Liguro-Catalan current (B) and the Northern drift with Atlantic influence $(\mathrm{C})$.

na, have been studied less (Dinet and Khripounoff, 1973; De Bovée et al., 1990).

In the present paper we document the level of preservation of the deep-sea floor phytodetritic material in relation to the oceanographic regime and the overlying phytoplankton biomass in late spring in 3 distinct areas: the Rhodanian slope, the Catalan slope and the North Balearic zone. We discuss the variations linked to the canyon's geomorphology, arguing and illustrating the importance of this phytodetritic material as a food source for meiofauna.

\section{SITES, MATERIALS AND METHODS}

During the EUROMARGE'95 cruise aboard the $\mathrm{R} / \mathrm{V}$ "Suroit" in the north western Mediterranean basin, one major task was a coordinated study of biogeochemical cycles with a prevalent focus on the water-sediment interface.
Samplings took place in three clearly distinct hydrodynamic areas: the Rhodanian slope, the Catalan slope and the North Balearic zone. A permanent nutrient enriched dome or ridge, extending from north of the Gulf of Lions to south-west of the Catalan Sea, is delineated by two "fronts" and their associated opposite currents (see refs in Introduction; Fig. 1). The Catalan front is characterized by a strong salinity gradient and the North Balearic front by a temperature gradient (Font, 1988). Schematically, three water masses coexist: a dense median dome and lighter waters of continental origin on the west side and of Atlantic origin on the east side. The position of the "fronts", central "divergence" and the presence of mesoscale cyclonic cells depend upon seasons and years (Font, 1988). From the hydrological descriptions of this Basin, two major phytoplankton provinces with well-marked differences can be identified: 1) on the western coast, an enriched water mass linked to the Catalan front; and, 
2) on the east side (North Balearic zone) phytoplankton with a lower biomass. Different assemblages characterise these two provinces (Estrada et al., 1989; Barlow et al., 1997).

Sampling of sediments and water masses was carried out in late spring (1995 June 5-16). Different canyon parts were sampled at each of the four prospected sites (Fig. 1): Head, Axis and Interfluve (Fig. 2). The sampling locations and dates are summarised in Table 1. Each station can be defined as follows: 1) the Planier station (PL) was at a 260 to $1180 \mathrm{~m}$ depth site located on the Rhodanian slope in the south-west Liguro-Provençal derive regime; 2) the Lacaze Duthiers (LD) and 3) Foix stations (FX) were located on the Catalan slope also in the southwest drift; and 4) the Balearic Islands station (BL) was located in the North Balearic basin in a northward drift regime.

Sediments were collected with the 12-core Wuttke multiple corer [described by Barnett et al. (1984) and produced by Fa. Wuttke, Hamburg]. This corer enables the sampling of well-preserved sedimentwater interface even at deep stations (Thiel et al., 1988-1989). At each site two cores (from two different casts) were analysed (Table 1), with the exception of the LD Interfluve, BL 1650 Axis, FX Axis and PL Head. Differences in pigment concentrations between duplicates (sub-samples from one core) were less than $5 \%$.
Immediately after sampling, cores were transferred to the laboratory. The water interface layer (about $5 \mathrm{~mm}$ ) was gently siphoned off the cores and sub-sampled for further analyses and tests $(5 \mathrm{ml} \mathrm{sub}$ sample filtered onto GF/F Whatman filters and stored frozen at $-20^{\circ} \mathrm{C}$ for subsequent pigment analysis; $10 \mathrm{ml}$ for epifluorescence microscopy study on board and $2 \mathrm{ml}$ isolated for revival test on board, see below). Then, the bottom water (the first 10 to $20 \mathrm{~cm}$ above the sediment) was siphoned off and sub-sampled (100 to $500 \mathrm{ml}$ filtered and stored in the same way as for the interface layer) for subsequent pigment analysis. The upper part of the cores was carefully sliced into 6 segments $(0-0.5$, $0.5-1,1-2,2-3,3-4$, and $4-5 \mathrm{~cm}$ ) and stored frozen at $-20^{\circ} \mathrm{C}$ for subsequent pigment analysis and dry weight evaluation. Storage for several months does not apparently affect the pigment concentrations (Gieskes and Kraay, 1983; Klein and Riaux-Gobin, 1991). A sub-sample $(0-0.5 \mathrm{~cm})$ fraction was preserved in formaldehyde for subsequent SEM examination.

Surface water samples were collected with NIO bottles. A 21 sub-sample was filtered on Wathman $\mathrm{GF} / \mathrm{F}$ filters and stored frozen at $-20^{\circ} \mathrm{C}$ for subsequent pigment analysis (Table 1). Chlorophyll $a$ (including isomers), $b$ and $c$ (Chl $a, b$ and $c$ ) and associated phaeopigments (Phaeo $a, b \& c$ ) were measured on acetone extracts using the spectrofluo-

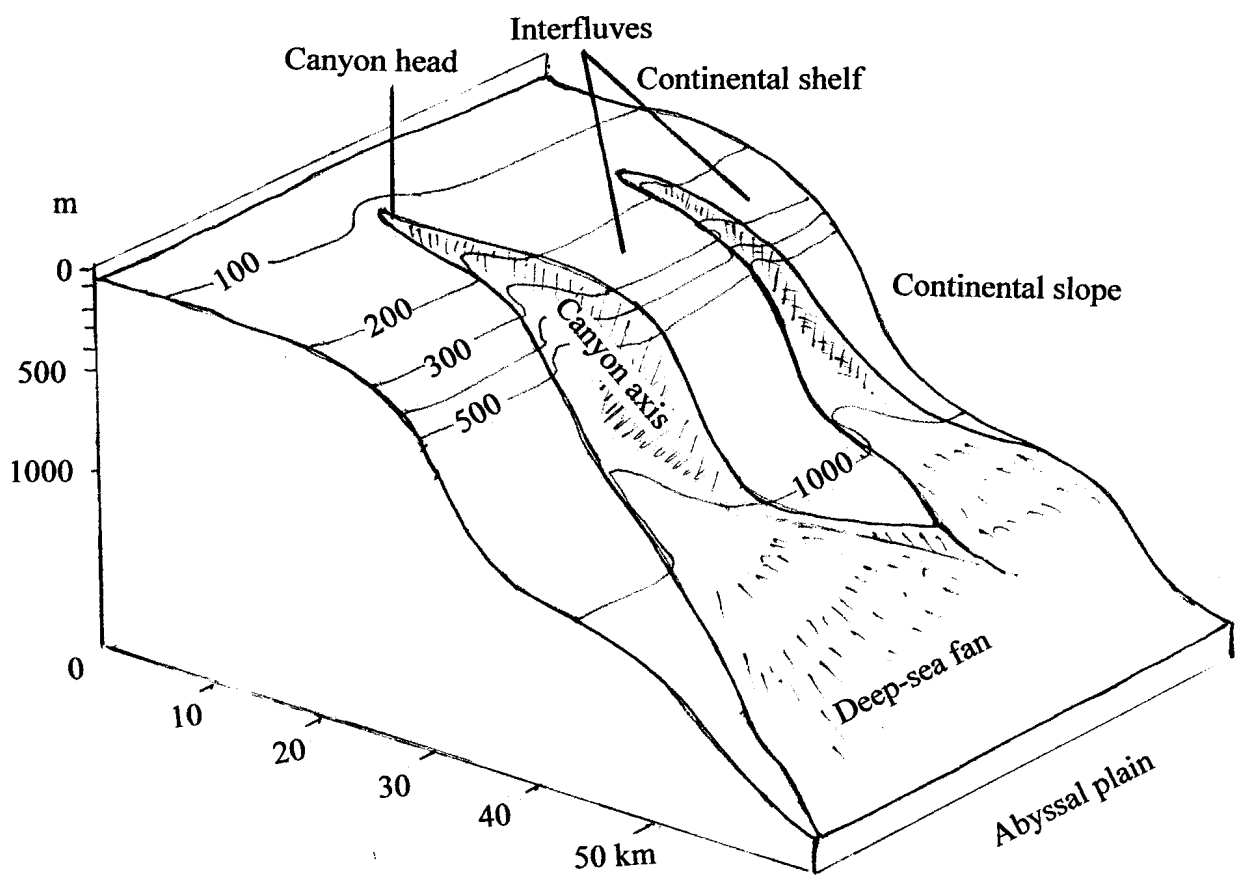

FIG. 2. - Schematic presentation of a canyon, with head, axis and interfluve parts, as mentioned in this study. 
TABLE 1. - List of sampling stations, geographical positions and sediment depths. St. $\mathrm{N}^{\circ}=$ number (see Fig. 1) and letter (see PCA Fig. 8); $\mathrm{KTB}=$ multiple corer; n.d. $=$ no data; dupl $=$ duplicates $) . \mathrm{PL}=$ Planier canyon; $\mathrm{LD}=$ Lacaze Duthiers canyon; $\mathrm{BL}=\mathrm{Balearic}$ Islands sites; $\mathrm{FX}=$ Foix canyon; Int $=$ interfluve.

\begin{tabular}{|c|c|c|c|c|c|c|c|}
\hline St. $\mathrm{N}^{\circ}$ & \multirow{2}{*}{$\begin{array}{l}\text { Cast type } \\
\mathrm{KTB}_{03}\end{array}$} & \multirow{2}{*}{$\begin{array}{l}\text { Station } \\
\text { PL Axis }\end{array}$} & \multirow{2}{*}{$\begin{array}{c}\text { Date } \\
5 / 6 / 95\end{array}$} & \multirow{2}{*}{$\begin{array}{l}\text { Latitude N } \\
43^{\circ} 00.72^{\prime}\end{array}$} & \multirow{2}{*}{$\begin{array}{c}\text { Longitude E } \\
5^{\circ} 11.63^{\prime}\end{array}$} & \multirow{2}{*}{$\begin{array}{r}\text { Depth (m) } \\
1180\end{array}$} & \multirow{2}{*}{$\begin{array}{c}\begin{array}{c}\text { Phyto. } \\
\text { surface }\end{array} \\
+\end{array}$} \\
\hline 1 & & & & & & & \\
\hline 1 & $\mathrm{KTB}_{05}$ & PL Axis & $5 / 6 / 95$ & $43^{\circ} 00.62^{\prime}$ & $5^{\circ} 11.61$ & 1180 & $\mathrm{nd}$ \\
\hline 2 & $\mathrm{KTB}_{06}$ & PL Int & $6 / 6 / 95$ & $42^{\circ} 58.97^{\prime}$ & $5^{\circ} 14.67^{\prime}$ & 915 & $\mathrm{nd}$ \\
\hline 2 & $\mathrm{KTB}_{10}$ & PL Int & $6 / 6 / 95$ & $43^{\circ} 00.47^{\prime}$ & $5^{\circ} 16.83$ & 630 & + \\
\hline 3 & $\mathrm{KTB}_{11}^{10}$ & PL Head & $6 / 6 / 95$ & $43^{\circ} 05.95^{\prime}$ & $5^{\circ} 14.79$ & 260 & + \\
\hline 4 & $\mathrm{KTB}_{16}$ & LD Axis & $8 / 6 / 95$ & $42^{\circ} 24.25^{\prime}$ & $3^{\circ} 37.56^{\prime}$ & 1175 & + \\
\hline 4 & $\mathrm{KTB}_{19}$ & LD Axis & $8 / 6 / 95$ & $42^{\circ} 24.29^{\prime}$ & $3^{\circ} 37.44^{\prime}$ & 1180 & $\mathrm{nd}$ \\
\hline 5 & $\mathrm{KTB}_{21}$ & LD Int. & $10 / 6 / 95$ & $42^{\circ} 25.71^{\prime}$ & $3^{\circ} 41.93$ & 775 & + \\
\hline 6 & $\mathrm{KTB}_{27}$ & BL Axis & $11 / 6 / 95$ & $40^{\circ} 13.02^{\prime}$ & $3^{\circ} 25.47^{\prime}$ & 1220 & + \\
\hline 6 & $\mathrm{KTB}_{28}$ & BL Axis & $11 / 6 / 95$ & $40^{\circ} 13.01$ & $3^{\circ} 25.54$ & 1220 & $\mathrm{nd}$ \\
\hline 7 & $\mathrm{KTB}_{29}^{20}$ & BL Int & $12 / 6 / 95$ & $40^{\circ} 13.95^{\prime}$ & $3^{\circ} 37.04$ & 585 & + \\
\hline 7 & $\mathrm{KTB}_{32}$ & BL Int & $12 / 6 / 95$ & $40^{\circ} 14.01^{\prime}$ & $3^{\circ} 37.00$ & 585 & $\mathrm{nd}$ \\
\hline 8 & $\mathrm{KTB}_{33}$ & BL 2000 & $13 / 6 / 95$ & $40^{\circ} 27.31$ & $3^{\circ} 43.38^{\prime}$ & 2070 & $\mathrm{nd}$ \\
\hline 8 & $\mathrm{KTB}_{34}$ & BL 2000 & $13 / 6 / 95$ & $40^{\circ} 27.17^{\prime}$ & $3^{\circ} 43.17^{\prime}$ & 2070 & + \\
\hline 9 & $\mathrm{KTB}_{37}$ & BL 1650 Axis & $13 / 6 / 95$ & $40^{\circ} 18.07^{\prime}$ & $3^{\circ} 12.26^{\prime}$ & 1650 & $\mathrm{nd}$ \\
\hline 10 & $\mathrm{KTB}_{40}$ & FX Int S & $15 / 6 / 95$ & $40^{\circ} 54.02^{\prime}$ & $1^{\circ} 47.05^{\prime}$ & 1040 & $+($ dupl) \\
\hline 10 & $\mathrm{KTB}_{42}$ & FX Int S & $15 / 6 / 95$ & $40^{\circ} 54.04^{\prime}$ & $1^{\circ} 47.07^{\prime}$ & 1045 & $\mathrm{nd}$ \\
\hline $11 \mathrm{I}$ & $\mathrm{KTB}_{44}$ & FX Axis & $16 / 6 / 95$ & $40^{\circ} 56.65^{\prime}$ & $1^{\circ} 54.68^{\prime}$ & 1310 & + \\
\hline $12 \mathrm{I}$ & $\mathrm{KTB}_{45}$ & FX Int N & $16 / 6 / 95$ & $40^{\circ} 58.02^{\prime}$ & $1^{\circ} 59.43^{\prime}$ & 1030 & $+($ dupl $)$ \\
\hline 12 & $\mathrm{KTB}_{47}$ & FX Int N & $16 / 6 / 95$ & $40^{\circ} 58.02^{\prime}$ & $1^{\circ} 59.43$ & 1040 & $\mathrm{nd}$ \\
\hline
\end{tabular}

rometric method of Neveux and Lantoine (1993). $\mathrm{GF} / \mathrm{F}$ filters were homogenized in $100 \%$ acetone (p.a. Merck) and kept cool and dark for $12 \mathrm{~h}$. Wet sediments $(1 \mathrm{~g} \pm 0.001 \mathrm{~g})$ were extracted (for $24 \mathrm{~h}$, $4^{\circ} \mathrm{C}$, in dark) in $10 \mathrm{ml} 90 \%$ acetone (p.a. Merck), without grinding or adding $\mathrm{MgCO}_{3}$, only shaking twice during the extraction time (the final concentration of acetone was never below $85 \%$; pigment degradation only appears below $80 \%$ ). Sub-samples of sediments were oven dried $\left(60^{\circ} \mathrm{C}\right)$ for dry weight evaluation. For scanning electron microscopy (SEM), small sub samples of subsurface sediments were filtered on Nuclepore filters $(1 \mu \mathrm{m}$ pore diameter), carefully washed with distilled water to remove salts, oven dried $\left(60^{\circ} \mathrm{C}\right)$, gold coated and observed with an Hitachi S 520 scanning electron microscope.

At each sampling station, cultures in $500 \mathrm{ml} \mathrm{F} / 2$ medium (Guillard and Ryther, 1962) were initiated immediately after sampling, with a $5 \mathrm{ml}$ inoculum of the water-sediment interface. In the first step these cultures were incubated under natural conditions on the ship deck at the temperature of the surface water masses. At the end of the cruise, the cultures were transferred to the laboratory under similar simulated conditions in a controlled culture chamber. Every 58 days these cultures were sampled for later $\mathrm{Chl} a$ analysis $(5 \mathrm{ml} \mathrm{GF} / \mathrm{F}$ filtered and stored frozen at $20^{\circ} \mathrm{C}$ ) and for microscope examination.
In order to evidence still living microphytes, qualitative epifluorescence tests were applied onboard (Zeiss microscope, obj. 40) on subsurface sediment sub-samples at each site.

Meiofauna was collected with cut-off plastic syringes $\left(5.31 \mathrm{~cm}^{2}\right.$ in section) used as small cores. Four sub-samples were taken in two different tubes of each multi-corer performed. The upper $5 \mathrm{~cm}$ of each mini-cores were preserved in $4 \%$ buffered formalin. The animals were sieved on a $40 \mu \mathrm{m}$ mesh and sorted by an adapted Silicagel-flotation technique (De Jonge and Bouwman, 1977) using Ludox HS-40. They were counted under a dissecting microscope and identified to higher taxa. Data are expressed in individuals per $\mathrm{m}^{-2}$ and $\mathrm{mg}$ per $\mathrm{m}^{-2}$ (see refs in EUROMARGE-NB Final Report: Dinet et al., 1996).

Simple regressions and a principal component analysis (PCA) were applied to a set of data $(n=15)$ concerning pigments, water content, sampling depth and meiofauna densities from the same cast at each site.

\section{RESULTS}

\section{Sediment description}

We had the opportunity to work on cores with a well-preserved interface in most cases. No real fluff was observed (only whitish vellum in some cases), 
TABLE 2. - Pigment concentrations in water masses (surface, bottom and overlying the sediment), surficial sediment ( $0-0.5 \mathrm{~cm}$ ). and batch culture after 20 days (see text for culture conditions). Surface $=$ surficial phytoplankton; bottom $=0-20 \mathrm{~cm}$ above sediment; interface $=1-5 \mathrm{~mm}$ above sediment. * duplicates (mean value); ** duplicates (the 2 values). $\mathrm{n} \mathrm{d}=$ no data. $(\mathrm{)}=$ dubious data. The duplicates were sampled with two different casts (see Table 1).

\begin{tabular}{|c|c|c|c|c|c|c|c|c|c|c|c|c|}
\hline \multirow{2}{*}{$\begin{array}{l}\text { Station } \\
\text { Rhodanian slope }\end{array}$} & \multirow{2}{*}{$\begin{array}{c}\text { Depth } \\
\mathrm{m}\end{array}$} & \multicolumn{2}{|c|}{$\begin{array}{l}\text { water masses } \\
\text { surface bottom interface }\end{array}$} & $\begin{array}{l}\text { interface } \\
\text { Chl } a\end{array}$ & \multicolumn{2}{|c|}{$\begin{array}{l}\text { sediment } \\
\quad(0-0.5 \mathrm{~cm})\end{array}$} & \multicolumn{3}{|c|}{$\begin{array}{l}\text { surface bottom }(0-0.5 \mathrm{~cm}) \\
\text { Chl } a\left[\mu \mathrm{g} \mathrm{^{-1 }}\right]\end{array}$} & \multicolumn{2}{|c|}{$\begin{array}{l}\text { Chl } a \text { / Chl } b \\
\text { water sediment } \\
\text { surface }(0-0.5 \mathrm{~cm})\end{array}$} & $\begin{array}{l}\text { culture tests } \\
\text { after } 20 \mathrm{~d}\end{array}$ \\
\hline & & & & & & & & & & & & \\
\hline \multicolumn{13}{|l|}{ Planier (PL) } \\
\hline -Head & 260 & 0.074 & 0.026 & 0.662 & 0.551 & 4.716 & 5.239 & 0.339 & 0.117 & 6.09 & 4.01 & 400 \\
\hline -Interfluve* & $630-915$ & 0.095 & 0.011 & 0.070 & 0.242 & 3.043 & 5.185 & 0.072 & 0.079 & 7.17 & 2.74 & $* * 0.1,50$ \\
\hline$\overline{\mathrm{x}}$ & & $(0.380)$ & 0.017 & 0.597 & 0.478 & 5.117 & 5.175 & 0.206 & 0.094 & $(10.11)$ & 3.25 & \\
\hline SDV & & $(0.512)$ & 0.008 & 0.498 & 0.209 & 2.301 & 0.069 & 0.133 & 0.020 & $(6.04)$ & 0.67 & \\
\hline \multicolumn{13}{|c|}{ Catalan slope } \\
\hline \multicolumn{13}{|c|}{ 1) Lacaze Duthiers (LD) } \\
\hline -Axis* & 1175 & 0.288 & 0.105 & 0.280 & 0.422 & 5.178 & 3.633 & 0.599 & 0.081 & 12.12 & 3.03 & $* 1,13$ \\
\hline \multicolumn{13}{|l|}{ 2) Foix (FX) } \\
\hline -Axis & 1310 & 0.172 & 0.030 & 0.036 & 0.826 & 10.772 & 5.122 & 0.104 & 0.077 & 5.14 & 2.62 & 0.08 \\
\hline -Interfluve $\mathrm{N}^{*}$ & 1030 & 0.095 & 0.011 & 0.028 & 0.294 & 4.500 & 2.960 & 0.129 & 0.061 & 6.00 & 2.43 & $* * 0.02,0.08$ \\
\hline -Interfluve S* & 1040 & 0.134 & 0.008 & 0.064 & 0.357 & 5.050 & 4.263 & 0.073 & 0.071 & 5.37 & 2.44 & $* * 0.07,0.09$ \\
\hline$\overline{\mathrm{x}}$ & & 0,226 & 0.033 & 0.091 & 0.429 & 5.806 & 3.790 & 0.194 & 0.072 & 7.79 & 2.59 & \\
\hline SDV & & 0.141 & 0.041 & 0.106 & 0.231 & 2.850 & 0.918 & 0.227 & 0.008 & 3.21 & 0.26 & \\
\hline \multirow{2}{*}{\multicolumn{13}{|c|}{$\begin{array}{l}\text { North Balearic zone } \\
\text { Baleares (BL) }\end{array}$}} \\
\hline & & & & & & & & & & & & \\
\hline -Axis* & 1220 & 0.069 & 0.006 & 0.068 & 0.161 & 2.022 & 6.133 & 0.006 & 0.080 & 5.02 & 1.74 & $* * 0.3,5$ \\
\hline -Interfluve & 585 & 0.072 & 0.008 & 0.023 & 0.295 & 3.166 & 5.007 & 0.008 & 0.078 & 4.21 & 2.03 & $* * 0.3,38$ \\
\hline -Bal. Ax. 1650 & 1650 & $\mathrm{nd}$ & 0.005 & 0.042 & 0.159 & 1.870 & $\mathrm{nd}$ & 0.074 & 0.085 & - & 1.39 & \\
\hline -Bal. 2000* & 2070 & 0.059 & 0.003 & 0.009 & 0.195 & 2.525 & 4.718 & 0.074 & 0.078 & 4.5 & 1.83 & ** $0.1,1.7$ \\
\hline$\overline{\mathrm{x}}$ & & 0.067 & 0.006 & 0.036 & 0.203 & 2.395 & 5.286 & 0.040 & 0.080 & 4.58 & 1.75 & \\
\hline SDV & & 0.007 & 0.002 & 0.026 & 0.064 & 0.585 & 0.747 & 0.034 & 0.003 & 0.41 & 0.27 & \\
\hline
\end{tabular}

indicating no recent microphytic sedimentation. Some differences were noticed in the macroscopic appearance of the sediment within each site, but also within the different parts of the canyons. At PL a red surficial layer (2-4 cm deep) due to Pechiney Industrial waste was observed. At BL the sediments appeared grey and more compact than on the Catalan slope and the microscopy test revealed the presence of coccoliths and absence of diatoms (pers. and Dugué obs.; SEM pictures not shown). On the western sites, diatoms were present at the same depth. As a general trend, the interfluve surficial sediments were fluid (high water content) within a more important depth than in the canyon axis. Macrofauna burrows were observed particularly at PL Int, LD axis and LD Int. These burrows suggested an active bioturbation on these sites, with no differentiation between axis and interfluve.

\section{Phytoplankton}

During this late spring, surface Chl $a$ concentrations (Table 2; Fig. 3) were relatively low (0.09 to
$0.34 \mu \mathrm{g} \mathrm{l}^{-1}$ ), with slightly higher values at LD (maximum $\left.0.4 \mu \mathrm{g} \mathrm{l}^{-1}\right)$. These results are in agreement with those reported by Conan et al. (1996) from a cruise a few weeks later at the same sites, with the exception of the high value at PL axis $\left(0.972 \mu \mathrm{g}^{-1}\right.$; Table 2), which may be dubious [such a high pigment concentration on the Rhodanian site was previously only reported on a coastal zone and during summer ( $\mathrm{M}_{1}$; Conan et al., 1996)], but the Chl $a$ concentration of the interface water at the same site was also high (Table 2). The North Balearic stations (BL) presented the lowest phytoplankton pigment amounts. The $\mathrm{Chl} a$ / Chl $c$ ratio was spatially constant (average: 3.5; no data shown), whereas the Chl $a / \mathrm{Chl} b$ ratio decreased significantly from north to south (7-10 to 4; Table 2).

\section{Bottom water and interface}

Very low pigment amounts characterised the deep overlying water (bottom water, $20 \mathrm{~cm}$ column above the sediment) at all sites (Table 2; highest values at LD axis, up to $0.105 \mu \mathrm{g} \mathrm{Chl} a \mathrm{l}^{-1}$ ). The $\mathrm{Chl} a$ 

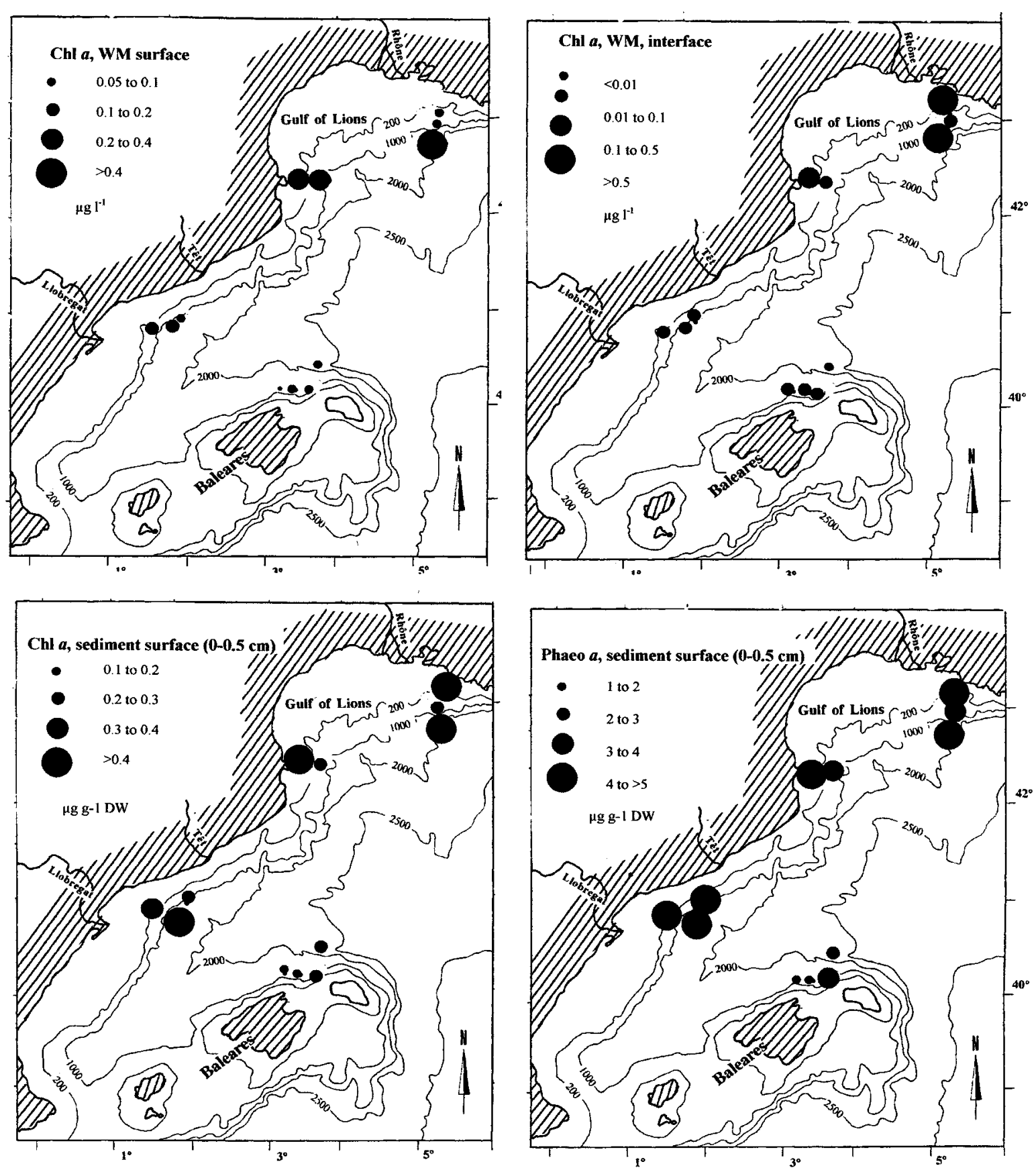

FIG. 3. - Spatial repartition of Chl $a$ in surface Water Masses (WM), water sediment interface, sediment surface $(0-0.5 \mathrm{~cm}$ layer) and Phaeo $a$ in sediment surface $(0-0.5 \mathrm{~cm}$ layer $)$.

/ Phaeo $a$ ratio, representative of the degree of degradation of the material, ranged from very low values $(<0.1)$ at BL to far higher values at PL head and LD axis ( 0.34 and 0.59 respectively). With the exception of these last two sites, no recent sedimentation has apparently taken place in other areas. Concerning the interface layer (the few $\mathrm{mm}$ above sediment; Table 2; Fig. 3), no real fluff was observed, and here again only PL axis and head and LD axis showed high values (0.66 to $\left.1.06 \mu \mathrm{g} \mathrm{Chl} a \mathrm{l}^{-1}\right)$, whereas at the other sites the concentrations were at the detection limit of the method.

\section{Sediment}

Duplicates within two different casts at the same site indicated a good reproducibility of results (around 10\% variation; cf. Table 2 in EUROMARGE-NB Final Report: Riaux-Gobin et al., 1996). Table 2 and Figure 3 give the pigment distri- 

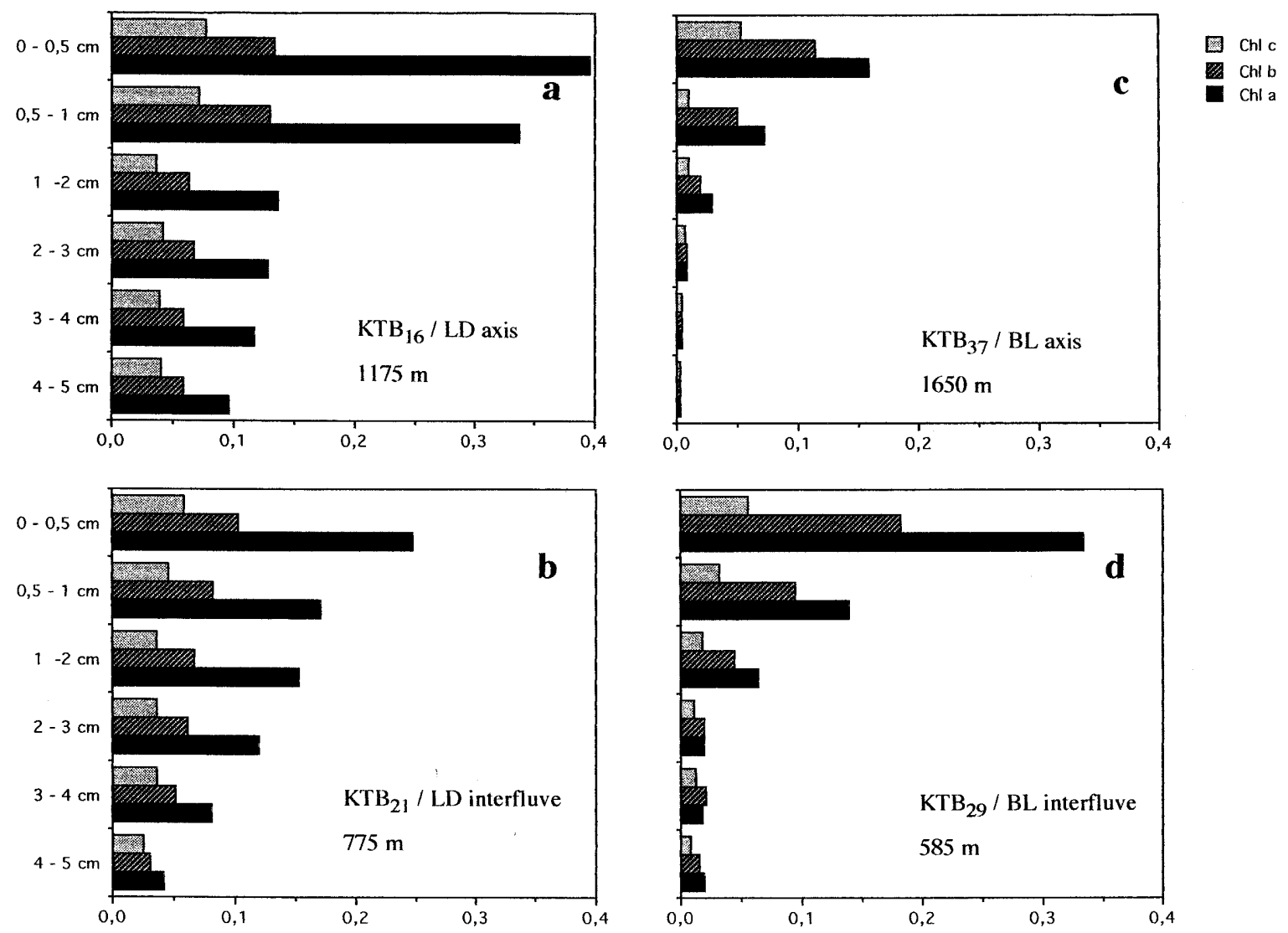

FIG. 4. - Vertical pigment gradients in sediments, in two contrasted zones: the Lacaze Duthiers canyon (enriched zone. 2a: LD axis; 2b: LD interfluve), and the Balearic Islands site (impoverished zone. 2c: BL axis; 2d: BL interfluve).

bution in the first $5 \mathrm{~mm}$ of sediments. Pigment concentrations were low (average of $0.37 \mu \mathrm{g} \mathrm{g}^{-1} \mathrm{dw} C \mathrm{Chl}$ $a$ and $4.49 \mu \mathrm{g} \mathrm{g}^{-1} \mathrm{dw}$ Phaeo $a$ ), with minimum values at BL $\left(0.17 \mu \mathrm{g} \mathrm{g}^{-1} \mathrm{dw} \mathrm{Chl} a\right)$. The Chl $a$ / Phaeo $a$ ratio was relatively constant in all layers of all sediments, ranging from 0.06 to 0.12 with no clear trend. Chl $a / \mathrm{Chl} c$ ratios were higher than in the overlying water (from 4 to 5 ; data not shown), whereas the $\mathrm{Chl} a$ / Chl $b$ ratio was lower at the sediment surface (from 1.3 to 4 ), probably due to a better preservation of $\mathrm{Chl} b$ (Chl $b$ is more stable than Chl $a$; Brown et al. 1977). On the other hand, a clear gradient of the $\mathrm{Chl} a$ / $\mathrm{Chl} b$ ratio was observed from 3.25 in the north to 1.75 in the $\mathrm{N}$ Balearic sites. From surface to deeper layers of sediments, a regular gradient of pigments was obvious at the interfluve stations (for example at LD and BL; Fig. 4 b and $\mathrm{d}$ ), whereas at the axis sites the gradient was more irregular (Fig. 4 a and c).

\section{Epifluorescence qualitative tests}

At PL some fluorescent cells (containing chloropigments) were detected on each part of the canyon (only in surface sediment); this fluorescent signal was often associated with faeces and aggregates. At LD some rare but apparently undamaged cells with red well-marked fluorescence (upon which Chaetoceros spore-like cells) were present mostly at LD axis. In contrast, at FX and BL no well-preserved cells were observed, only faeces with a very low, greenish signal.

\section{Revival tests}

The revival tests (Culture tests; Table 2) were positive for the northern sampling stations (PL, LD), whereas at FX and BL they were not significant (see illustration in EUROMARGE-NB Final Report: Riaux-Gobin et al., 1996). The duplicates (cultures initiated with samples of 2 different casts at the same site; Table 2), even if not exactly similar, roughly indicated the same tendency. There was no revival at $\mathrm{FX}$, very low response at $\mathrm{BL}$, positive but low response at LD and rapid response at PL head and PL axis, whereas the response at PL interfluve was less positive. The level of response was apparently not linked to the depth. Moreover, the highest 
pigment concentrations in the sediment were not always linked to a positive response of the culture (i.e. FX axis; Table 2). These cultures attest that at the PL and LD stations some microphytes were still living when sampled. Some light microscope investigations on these cultures were performed at the end of the experiments: these assemblages were dominated by well growing planktonic microalgae, particularly Chaetoceros spp (the culture makes the determination at species rank difficult).

\section{DISCUSSION}

\section{Geographical areas in the NW Mediterranean basin}

Following the present phytoplankton data, and in agreement with the previous works (i.e. refs. cit.), the east part of the North Balearic Basin (BL) is an impoverished (oligotrophic) area, whereas the Rhodanian slope (PL) and the Catalan slope (LD and FX) exhibited higher pigment concentrations, partly related to river discharge (Masó and Duarte, 1989). Moreover, the Chl $a$ / Chl $b$ ratio decreased from north to south. Chl $b$ is a marker of Chlorophyta and Prochlorophyta (Rowan, 1989; Buma et al., 1991). The low Chl $a$ / Chl $b$ ratio characterises the dominance of population by these organisms. Thus, the results suggest that different assemblages are linked to each water mass, its origin and its hydrodynamics, in agreement with previous studies (Estrada et al., 1989; Barlow et al., 1997). The Chl $a$ / Phaeo $a$ ratio also exhibited differences within areas: on the Rhodanian slope (PL site) this ratio was homogenous from the coast to off-shore, though this was not the case at the other sites, indicating different origins of the water masses (i.e. refs. cit.) or the presence of meso-scale hydrodynamic cells.

An interesting new fact is that the deep-sea benthos reflects not only the differences between the pigments richness (a), but also the pigment diversity (b) of the overlying water masses of the three areas, even after particle sedimentation and grazing.

a) Figure 5 illustrates the relationships between the phytoplankton biomass in surface waters and in deep-sea sediment surface. A significant correlation appears within BL, PL and FX $(r=0.74$, significant at $\mathrm{P}=0.01)$. When LD is also taken into account, the correlation is not significant $(r=0.39)$. During the sampling period, the sediments of the Lacaze Duthiers canyon (LD) do not reflect the richness of the overlying phytoplankton. On the other hand, the meiofauna is particularly abundant at this site, probably with intense grazing. A similar trend is also noticed if we compare the bottom water $(20 \mathrm{~cm}$ water column overlying the sediments) and the overlaying surface water pigment concentrations: a positive (direct) correlation exists (not illustrated), but with a weak significance $(r=0.3924, n=10)$; here again, if LD is not included in the calculations, the relationship is stronger $(r=0.57)$.

Observations in epifluorescence and revival tests roughly agree with these assumptions: a better preservation at the sediment-water interface seems to occur in the areas where the overlying waters are phytoplankton-enriched (northern stations), with no well marked relation to depth. In the north Balearic zone (BL) all parameters (even the meiofaunal density, Fig. 6 A) indicated a reduced richness of the interface, related to the low phytoplankton concentrations in the upper water masses.

b) The geographical gradient in the $\mathrm{Chl} a$ / $\mathrm{Chl} b$ ratio in sediment surface roughly follows those of the overlying phytoplankton (Table 2). Moreover, the absence of diatom frustules in deep-sea sediments in the south part of the NW Mediterranean basin (BL), and coccoliths present everywhere, reflect the geographical diversity of the phytoplankton assemblages.

Moreover, the degree of compaction and appearance of BL sediments (light/whitish grey colour), which are different from those of the west part of the Basin, are also noticeable. The Balearic platform is carbonate-enriched (Canals and Ballesteros, 1997), partly due to a lack of fluvial inputs, favouring the settlement of carbonate benthic communities and carbonate particles, whereas the north-west Mediterranean margin is dominated by terrigenous inputs. The phytoplankton assemblages of the south part of the NW Mediterranean, mainly lacking large diatoms (refs. cit.) may also explain the carbonatedominated sedimentation at BL.

\section{Variations linked to canyon geomorphology}

In Table 3 we compare the results for different parts of a canyon during spring-summer (unpublished data from MEDIMAR cruises and present study): The Axis and Interfluve of the LacazeDuthiers canyon (LD). We had the opportunity to sample this canyon over several years, from 1991 to 1995 (present data), in similar conditions, using a multiple corer and the same pigment analysis methodology. 
TABLE 3. - Lacaze Duthiers site (LD, spring-summer period). Axis and Interfluve comparison in pigment biomass (surficial sediments: 0-0.5 $\mathrm{cm}$ ). $\mathrm{n}$. dupl. = no duplicates. All samples performed with a multiple corer (unpublished data from MEDIMAR campaigns and present EUROMARGE 95 data).

\begin{tabular}{|c|c|c|c|c|c|c|c|c|c|c|c|c|}
\hline \multirow[b]{2}{*}{ Date } & \multirow[b]{2}{*}{ lat $\mathrm{N}$} & \multirow[b]{2}{*}{ long $\mathrm{E}$} & \multicolumn{3}{|c|}{ AXIS } & \multirow[b]{2}{*}{$\begin{array}{c}\text { Chl } a \text { / } \\
\text { Phaeo } a\end{array}$} & \multirow[b]{2}{*}{ lat $\mathrm{N}$} & \multirow[b]{2}{*}{ long $\mathrm{E}$} & \multicolumn{2}{|c|}{ INTERFLUVE } & \multirow[b]{2}{*}{$\begin{array}{l}\text { Phaeo } a \\
{\left[\mu \mathrm{g} \mathrm{g}^{-1} \mathrm{dw}\right]}\end{array}$} & \multirow[b]{2}{*}{$\begin{array}{l}\text { Chl } a \text { / } \\
\text { Phaeo } a\end{array}$} \\
\hline & & & $\begin{array}{l}\text { Depth } \\
\text { m }\end{array}$ & $\begin{array}{c}\mathrm{Chl}_{\left[\mu \mathrm{g}^{-1}\right.} a \\
\mathrm{dw}]\end{array}$ & $\begin{array}{l}\text { Phaeo } a \\
\text { ] }\end{array}$ & & & & $\begin{array}{l}\text { Depth } \\
\text { m }\end{array}$ & Chl $a$ & & \\
\hline April 199 & $142^{\circ} \underset{\text {. }}{21.91}$ & $3^{\circ} 55.50^{\prime}$ & 1540 & $\begin{array}{l}0.141 \\
0.176\end{array}$ & $\begin{array}{l}3.722 \\
3.654\end{array}$ & $\begin{array}{l}0.038 \\
0.048\end{array}$ & $42^{\circ} \underset{،}{26.43}$ & $3^{\circ} 40.88^{\prime}$ & 760 & $\begin{array}{l}0.076 \\
0.145\end{array}$ & $\begin{array}{l}1.839 \\
3.852\end{array}$ & $\begin{array}{l}0.041 \\
0.038\end{array}$ \\
\hline July 1991 & “ & & “ & $\begin{array}{c}0.138 \\
\text { n. dupl }\end{array}$ & 3.118 & 0.044 & “ & & “" & $\begin{array}{l}0.128 \\
0.084\end{array}$ & $\begin{array}{l}3.342 \\
2.033\end{array}$ & $\begin{array}{l}0.038 \\
0.041\end{array}$ \\
\hline May 1992 & “" & & “" & $\begin{array}{l}0.125 \\
0.303\end{array}$ & $\begin{array}{l}2.534 \\
5.844\end{array}$ & $\begin{array}{l}0.093 \\
0.052\end{array}$ & " & & “" & $\begin{array}{l}0.198 \\
0.136\end{array}$ & $\begin{array}{l}4.301 \\
4.058\end{array}$ & $\begin{array}{l}0.046 \\
0.034\end{array}$ \\
\hline Mar. 1993 & “ & & “ & $\begin{array}{c}0.098 \\
\text { n. dupl. }\end{array}$ & 2.763 & 0.035 & n. dupl. & & “ & 0.076 & 1.839 & 0.041 \\
\hline $\begin{array}{l}\text { June } 1995 \\
\text { (present } \\
\text { study) }\end{array}$ & $\begin{array}{l}42^{\circ} 24.25^{\prime} \\
42^{\circ} 24.29^{\prime}\end{array}$ & $\begin{array}{l}3^{\circ} 37.57^{\prime} \\
3^{\circ} 37.44^{\prime}\end{array}$ & $\begin{array}{l}1175 \\
1180\end{array}$ & $\begin{array}{l}0.396 \\
0.447\end{array}$ & $\begin{array}{l}5.059 \\
5.296\end{array}$ & $\begin{array}{l}0.078 \\
0.084\end{array}$ & $\begin{array}{c}42^{\circ} 25.71 \\
\text { n. dupl.. }\end{array}$ & $3^{\circ} 41.94^{\prime}$ & 775 & 0.248 & 3.531 & 0.070 \\
\hline $\begin{array}{l}\bar{x} \\
\text { SDV }\end{array}$ & & & & $\begin{array}{l}0.228 \\
0.135\end{array}$ & $\begin{array}{l}3.998 \\
1.245\end{array}$ & $\begin{array}{l}0.059 \\
0.023\end{array}$ & & & & $\begin{array}{l}0.138 \\
0.062\end{array}$ & $\begin{array}{l}3.099 \\
1.034\end{array}$ & $\begin{array}{l}0.044 \\
0.011\end{array}$ \\
\hline
\end{tabular}

Pigment concentrations are higher in the axis of the canyon, but very slightly and with exceptions (Table 3). The Chl $a$ / Phaeo $a$ ratio does not show any significant differences within the two parts of the canyon. As previously suggested (Monaco et al., 1990; Buscail et al., 1990; Courp and Monaco, 1990), advection and channelisation may not be the only sedimentation and accumulation processes involved. In frontal zones, "pulse" sedimentation may also induce temporary higher particulate material concentrations in axis canyons, as well as in deep interfluves. In agreement with this hypothesis,

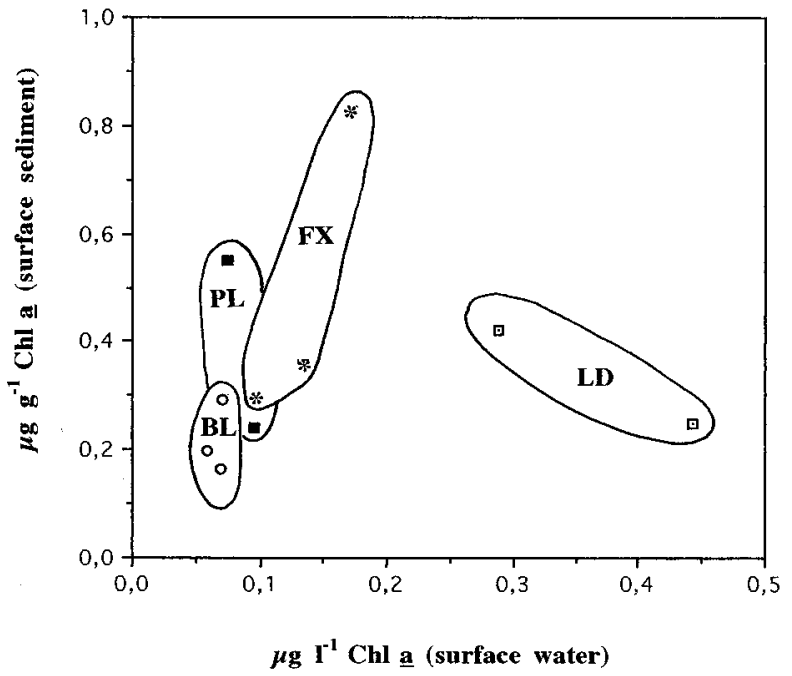

FIG. 5. - Relationships between pigment content of the sediments $\left(0-0.5 \mathrm{~cm}\right.$ layer; $\left.\mu \mathrm{g} \mathrm{g}^{-1} \mathrm{Chl} a \mathrm{dw}\right)$ and the surface water masses $\left(\mu \mathrm{g} \mathrm{l} \mathrm{l}^{-1} \mathrm{Chl} a\right)$. numerous macrofauna burrows (pers. obs. during MEDIMAR campaign, and present cruise) suggested an active bioturbation at these sites, with no differentiation between axis and interfluve. These observations (burrows not restricted to canyon axis) fit closely to those extensively reported in EUROMARGENB Final Report by Grehan and Keegan (1996).

At BL, where phytoplankton biomass is low, the underlying sediments were also impoverished (cf. Fig. 5), and no difference appeared within axis or interfluve pigment concentrations. Bioturbation (as suggested from Macrofauna burrows presence) was scarcer at BL than in the Catalan or Rhodanian zones.

Furthermore, a seasonal trend seems to exist in these deep-sea sediments: the higher pigment concentrations at LD were reported in late spring (MayJune, whenever axis or interfluve), whereas in March-April concentrations were low (Table 3), and very low concentrations were observed in winter (LD interfluve, 1991: 0.022 to $0.08 \mu \mathrm{g} \mathrm{Chl} a \mathrm{~g}^{-1} \mathrm{dw}$ ). Such seasonality in phytodetritus deposition in the Gulf of Lions has been previously documented in relation to meiofauna (De Bovée et al., 1990).

\section{Sedimented phytodetritus as a food source for meiofauna}

Another interest of this study was to point out connexions within phyto-biodeposits and Meiofauna, and to discriminate the influence of hydrology, geomorphology (particularly in canyons) and depth 
TABLE 4. - Meiofauna (0-5 cm layer). Data from the same cores cast as for pigments data (see Table 2, and ACP). Duplicates from different cores. $\mathrm{n}$. d. = no data

\begin{tabular}{|c|c|c|c|c|c|c|}
\hline Station & $\begin{array}{r}\text { Depth } \\
\text { m }\end{array}$ & $\operatorname{map} \mathrm{N}^{\circ}$ & $\begin{array}{c}\text { nematodes } \\
\text { indiv. } \\
10 \mathrm{~cm}^{-2}\end{array}$ & $\begin{array}{c}\text { copepods } \\
\text { indiv. } \\
10 \mathrm{~cm}^{-2}\end{array}$ & $\begin{array}{c}\text { total } \\
\text { Meiofauna } \\
10 \mathrm{~cm}^{-2}\end{array}$ & $\begin{array}{l}\text { biomass } \\
\text { Meiofauna } \\
\mathrm{mg} \mathrm{m}^{-2}\end{array}$ \\
\hline \multicolumn{7}{|l|}{ Rhodanian slope } \\
\hline \multicolumn{7}{|l|}{ Planier (PL) } \\
\hline -Head & 260 & 3 & 1028 & 117 & 1190 & 304.9 \\
\hline -Axis & 1180 & 1 & 1047 & 45 & 1130 & 237 \\
\hline -Axis & 1180 & 1 & 838 & 30 & 889 & 183 \\
\hline -Interfluve & 630 & 2 & 855 & 34 & 936 & 190 \\
\hline -Interfluve & 630 & 2 & 1049 & 58 & 1154 & 250 \\
\hline \multicolumn{7}{|c|}{ Catalan slope } \\
\hline \multicolumn{7}{|c|}{ 1) Lacaze Duthiers (LD) } \\
\hline -Axis & 1175 & 4 & 1397 & 58 & 1470 & 314 \\
\hline -Axis & 1175 & 4 & 1360 & 36 & 1440 & 285 \\
\hline -Interfluve & 775 & 5 & 1230 & 58 & 1350 & 284 \\
\hline \multicolumn{7}{|l|}{ 2) Foix (FX) } \\
\hline -Axis & 1310 & 11 & 1049 & 15 & 1140 & 207 \\
\hline -Interfluve N & 1030 & 12 & 804 & 9 & 885 & 157 \\
\hline -Interfluve $\mathrm{N}$ & 1030 & 12 & 190 & 0 & 196 & 35 \\
\hline -Interfluve S & 1040 & 10 & 987 & 13 & 1040 & 194 \\
\hline \multicolumn{7}{|c|}{ North Balearic zone } \\
\hline \multicolumn{7}{|c|}{ Baleares (BL) } \\
\hline -Axis & 1220 & 6 & 384 & 21 & 42.2 & 91 \\
\hline -Axis & 1220 & 6 & 934 & 38 & 99.6 & 209 \\
\hline -Interfluve & 585 & 7 & 1098 & 40 & 116 & 240 \\
\hline -Bal. Ax. 1650 & 1650 & 9 & n. d. & n. d. & n. d. & n. d. \\
\hline -Bal. 2000 & 2070 & 8 & 292 & 17 & 32.6 & 70 \\
\hline -Bal. 2000 & 2070 & 8 & 288 & 13 & 33.5 & 66 \\
\hline
\end{tabular}
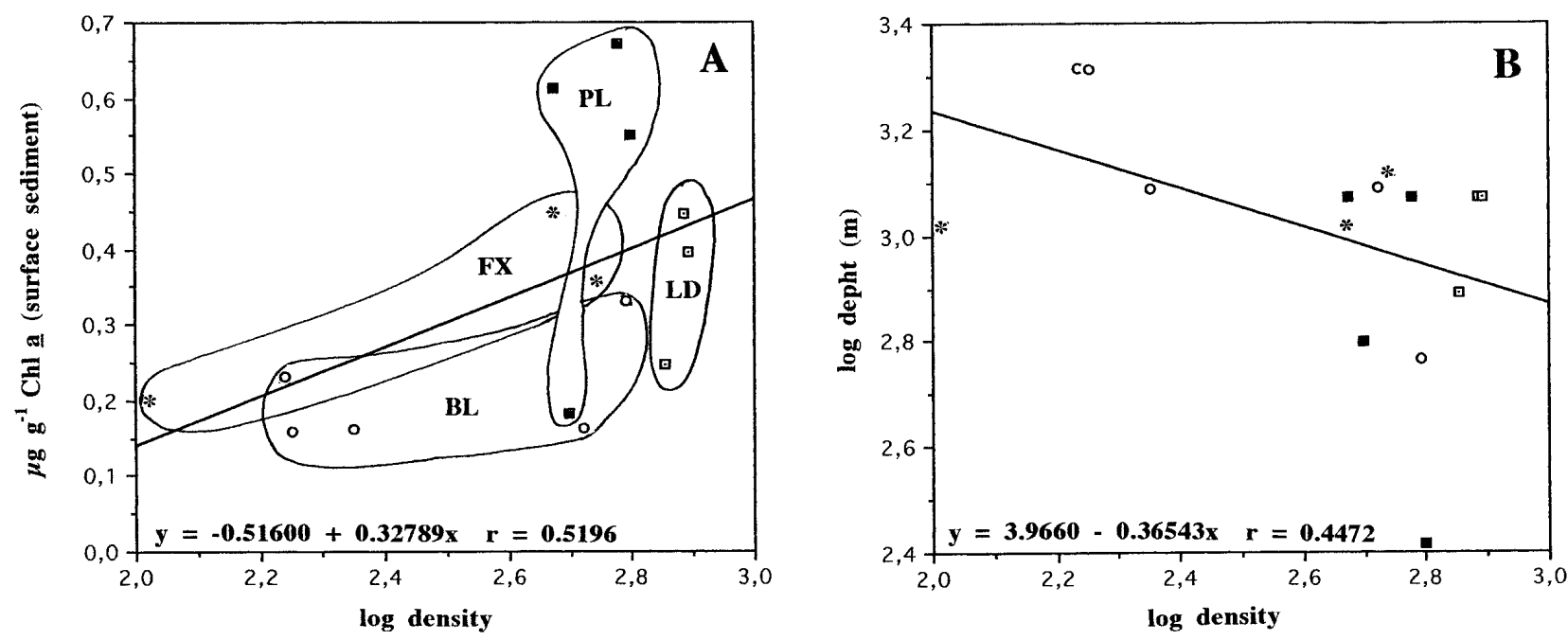

FIG. 6. - A) relationships between Meiofauna density (log ind. $5.31 \mathrm{~cm}^{-2}$; see Table 4) and the pigment content of the surface sediments ( $\mu \mathrm{g} \mathrm{g}^{-1} \mathrm{Chl} a \mathrm{dw}$; see Table 2). B) relationships between Meiofauna density (log ind. $5.31 \mathrm{~cm}^{-2}$; see Table 4) and the depth (log m).

of the sites. Previous works in the NW Mediterranean (Dinet et al., 1973; De Bovée et al., 1990) pointed out the relatively low Meiofaunal densities. The relationships within biodeposition and Meiofauna have been documented in the Mediterranean (De Bovée et al., 1990) and also in other sea margins or deep-sea sediments (Dinet and Khripounoff, 1982), and were recently documented by
Pfannkuche et al. (1999) in the north-east Atlantic, and by Pfannkuche et al. (2000) in the deep Arabian Sea. The present data (Table 4; Fig. 7), point out relationships within meiofauna and (a) abiotic and (b) biotic factors (Table 5).

a) The good relationships between copepods and sediment pore water content (significant at $\mathrm{P}=0.05$ ) may be explained by their preference for fluid sedi- 
TABLE 5. - Linear regression coefficients between major parameters in surficial sediments of the studied sites (PL, LD, BL, FX), i.e.: Chl $a$, $\mathrm{Chl} b$, Phaeo $a$ concentrations, sediment pore water content (\% p.w.), total Meiofauna abundance, nematodes and copepods abundance (and pigment ratios as indication, see comments in text, and PCA illustration). $\mathrm{n}=15 ; *=$ significant at $\mathrm{p}=0.05$

\begin{tabular}{|c|c|c|c|c|c|c|c|c|c|c|}
\hline & Chl $a$ & Phaeo $a$ & Chl $b$ & Nem. & Cop. & Meio. & \%p.w.. & Depth & $\begin{array}{l}\text { Chl } a \text { / } \\
\text { Chl } b\end{array}$ & $\begin{array}{l}\text { Chl } a \text { / } \\
\text { Phaeo } a\end{array}$ \\
\hline Chl $a$ & 1 & $.95^{*}$ & $.87 *$ & $.49 *$ & .41 & $.50 *$ & .15 & .28 & .75 & .46 \\
\hline \multicolumn{2}{|l|}{ Phaeo $a$} & 1 & $.88^{*}$ & .47 & .18 & .46 & .36 & .15 & .64 & .18 \\
\hline \multicolumn{2}{|l|}{ Chl $b$} & & 1 & .39 & .11 & .38 & .38 & .09 & .34 & .29 \\
\hline \multicolumn{2}{|l|}{ Nem. } & & & 1 & $.58 *$ & $.99 *$ & .06 & $.52 *$ & .51 & .28 \\
\hline \multicolumn{2}{|l|}{ Cop. } & & & & 1 & $.62 *$ & $.57 *$ & $.60 *$ & .68 & .77 \\
\hline \multicolumn{2}{|l|}{ meio. } & & & & & 1 & .08 & .54 & .54 & .32 \\
\hline \multicolumn{2}{|l|}{$\%$ p.w. } & & & & & & 1 & $.57 *$ & .29 & .54 \\
\hline \multicolumn{2}{|l|}{ Depth } & & & & & & & 1 & .53 & .50 \\
\hline \multicolumn{3}{|c|}{$\mathrm{Chl} a / \mathrm{Chl} b$} & & & & & & & 1 & .52 \\
\hline \multicolumn{3}{|c|}{ Chl $a$ / Phaeo $a$} & & & & & & & & 1 \\
\hline
\end{tabular}
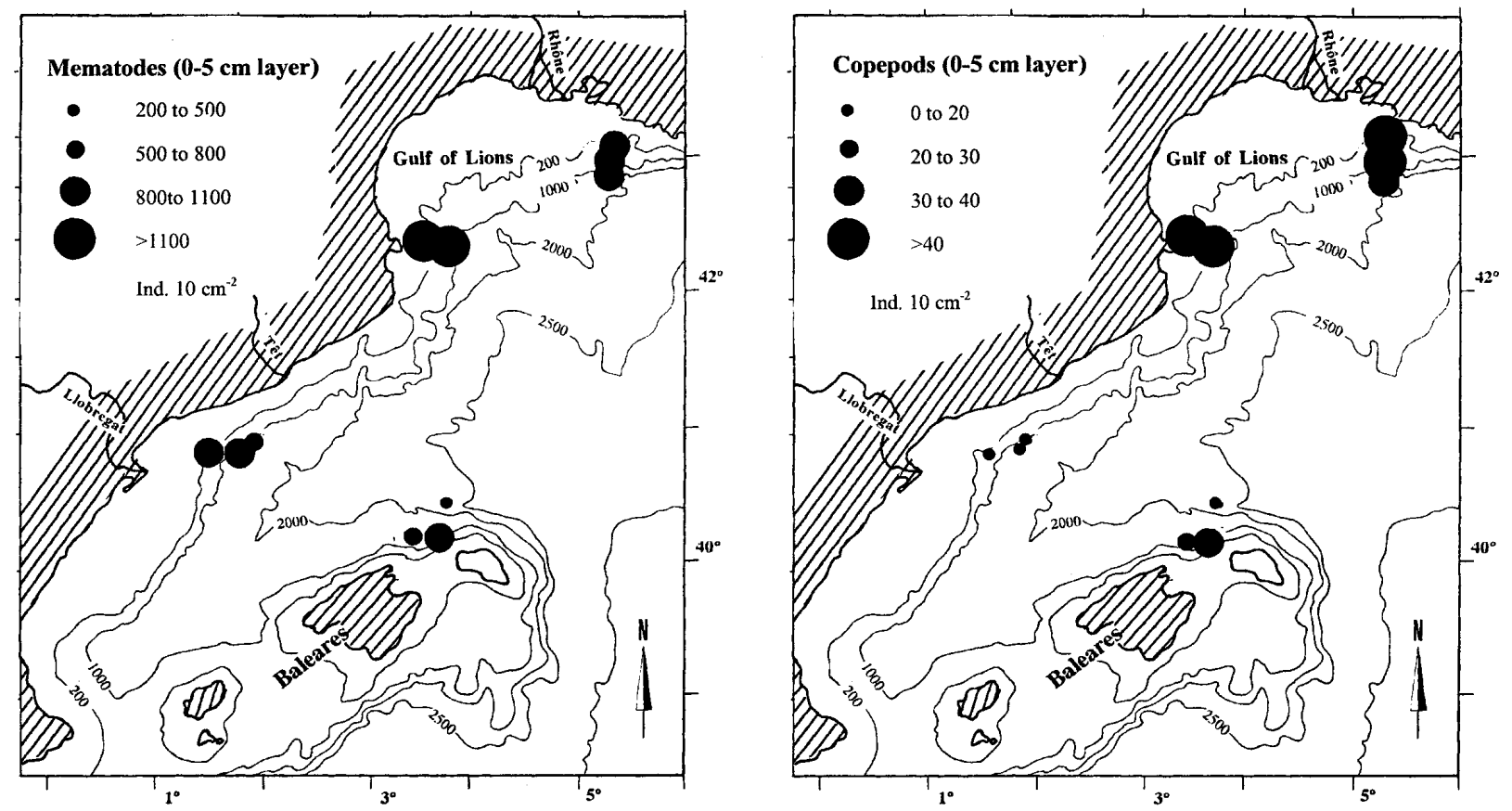

FIG. 7. - Spatial distribution of nematodes and copepods in the sediment surface $(0-5 \mathrm{~cm}$ layer $)$.

ments. In agreement with previous works (see refs. in De Bovée et al., 1990), meiofauna density is classically negatively related to depth (but with a low significance $\mathrm{p}=0.1$; Fig. $6 \mathrm{~B}$ ). Between the axis and interfluve canyon parts, the Meiofauna densities were not significantly different (Table 4).

b) As illustrated by simple correlations (Table 5; Fig. 6A) and PCA (Figs 8 A \& B), Meiofauna abundance was positively related to $\mathrm{Chl} a$ concentration in surficial sediments (significant at $\mathrm{P}=0.05$ ), this relation being more strong/significant than those with depth. Chl $a$ concentration was more or less independent of depth (Table 5). Moreover, a stronger relationships exists between Meiofauna and Chl $a$ than within degraded pigments (Phaeo $a$ ). Thus, Meiofauna seemed to respond rapidly to freshly sedimented material. These results fit well with the relationships also described by Alongi 

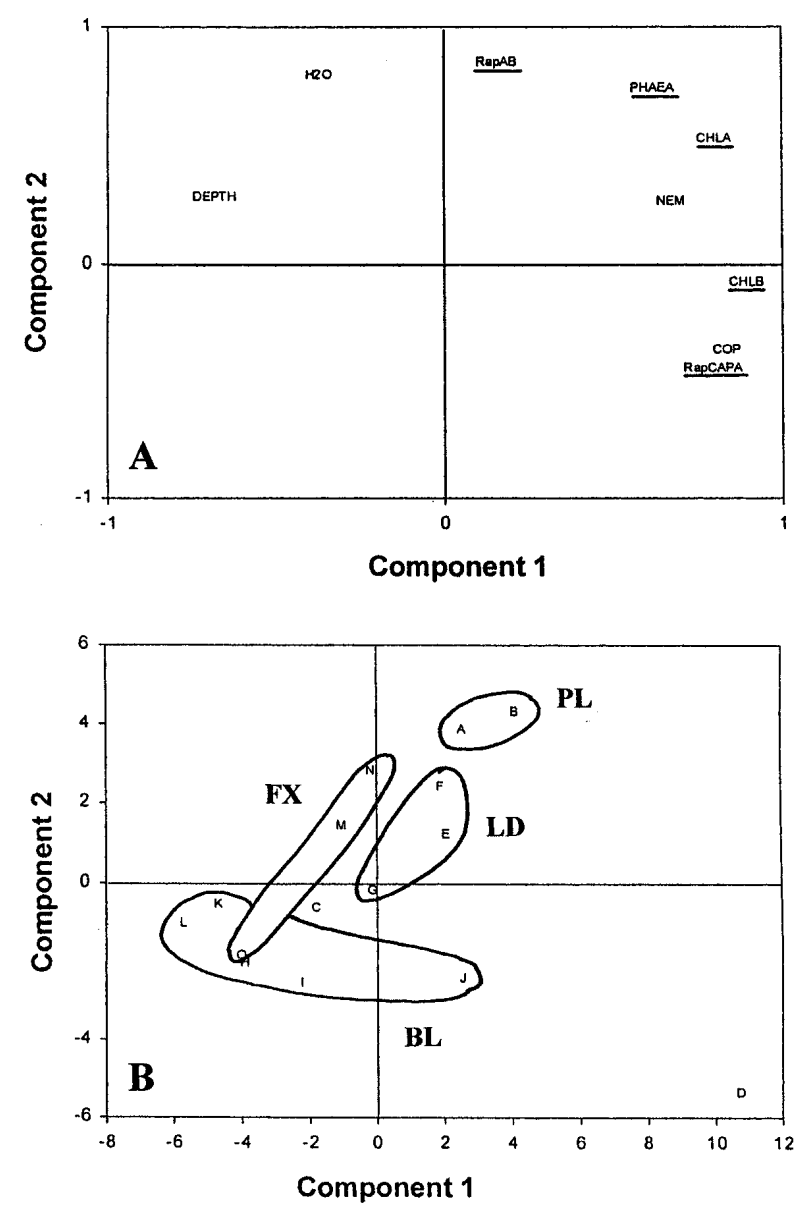

FIG. 8. - Principal Component Analysis (PCA). Illustration of the 2 first axes. A) parameters $(\mathrm{RapAB}=\mathrm{Chl} a / \mathrm{chl} b$ ratio; $\operatorname{RapCAPA}=$ Chl $a /$ Phae ratio; CHLA $=$ Chl $a$; PHAEA $=$ Phaeo $a$ and CHLB $=$ Chl $b$ ). B) sampling sites (for abbreviations, see Table 1).

(1992) and Danovaro et al. (1995) between deep-sea benthic communities and available organic biodeposits. On the other hand, nematodes (major component of Meiobenthos) and copepods seem to have a dissimilar response to similar factors (PCA, Figs 8 and Table 5): copepods seem to be positively related to the Chl $a$ / Phaeo $a$ ratio, and to the freshness of the biodeposit. As they are in part detritivorous (McIntire, 1969; Pfannkuche et al., 2000), nematodes seem to be less dependent than copepods upon the freshness of the pigmented material. The Chl $a$ / $\mathrm{Chl} b$ ratio also seems to influence the Meiobenthos spatial repartition (see Table 5).

\section{CONCLUSION}

Two different sectors in the NW Mediterranean basin are evidenced from the spatial distribution of pigments in surface water and the deep-sea floor:
- The NW and W margins (Rhodanian and Catalan slopes) were phytoplankton-enriched, and exhibited a relatively high pigment content in sediments, with the exception of the southern part (Foix canyon), and high Meiofauna densities.

- The North Balearic zone was phytoplanktonimpoverished, and exhibited very low pigment concentrations in sediments, associated with lower Meiofauna densities.

These results, also confirmed by the revival tests, fit well with the presence of the median Catalan front (see refs. cit., Introduction), separating two well-defined zones with contrasted hydrodynamics: 1) The Liguro-Provençal derive on north with major river discharges, and 2) the northward Balearic drift with Atlantic influence on the south (see Fig. 1).

The present data confirm that organic compounds such as microphyte pigments, as well as their ratios, can be used as a reliable proxy for present-or recent-sedimentation events, and can be the fingerprints of the hydro-climatic conditions that prevailed in the overlying water masses in the weeks before. The frontal Catalan zone, as defined by Estrada and Margalef (1988; see Introduction), which is demonstrated to be phytoplankton-enriched despite a relatively low biomass in surficial waters, particularly during the present EUROMARGE 95 cruise, seems to induce local sedimentation and accumulation of Particulate Organic Carbon, and particularly chloropigments, which support the settlement and an active development of deep-sea Meiofauna.

\section{ACKNOWLEDGEMENTS}

Thanks are due to the officers and crew of the $\mathrm{R} / \mathrm{V}$ "Suroit" and the fellow scientists in the cruise for their cooperation in collecting samples, and also to Dimitri Gorand (Perpignan University) for SEM assistance and to Dr. Jacques Neveux (for the spectrofluorometric method) and Dr. Chantal Descolas-Gros (in charge of the MEDIMAR campaign). Thanks are also due to Philippe Albert for his helpful technical assistance onboard and in the laboratory. This work is part of the EUROMARGE Mast II Programme, EU, and the ECOMARGE pro parte France-JGOFS programme (unpublished data from the MEDIMAR campaign). We also acknowledge the logistic and financial support of CNRS. 


\section{REFERENCES}

Alongi, D.M. - 1992. Bathymetric patterns of deep-sea benthic communities from bathyal to abyssal depths in the western South pacific (Solomon and Coral Seas). Deep-Sea Res., 39: 549-565.

Barlow, R.G., R.F.C. Mantoura, D.G. Cummings and T.W. Fileman. - 1997. Pigment chemotaxonomic distributions of phytoplankton during summer in the western Mediterranean. DeepSea Res. II, 44: 833-850.

Barnett, P.R.O., J. Watson and D. Connely. - 1984. A multiple corer for taking virtually undisturbed samples from shelf, bathyal and abyssal sediments. Oceanol. Acta, 7: 399-408.

Beaulieu, S.E., K.L Smith, Jr. - 1998. Phytodetritus entering the benthic boundary layerand aggregated on the sea floor in the abyssal NE Pacific: macro- and microscopic composition. Deep-Sea Res. II, 45: 781-815.

Billett, D.S.M., R.S. Lampitt, A.L. Rice and R.F.C. Mantoura. 1983. Seasonal sedimentation of phytoplankton to deep-sea benthos. Nature, 302: 520-522.

Bouloubassi, I., E. Lipiatou, A. Saliot, I. Tolosa, J. M. Bayona and J. Albaignés. - 1990. Carbon sources and cycle in the western Mediterranean-the use of molecular markers to determine the origin of organic matter. Deep-Sea Res. II, 44: 781-799.

Brown, S.R., R.J. Daley and M.D. MacNeely. - 1977. Composition and stratigraphy of the fossil phorbin derivatives of Little Round Lake, Ontario. Limnol. Oceanogr., 22: 336-348.

Buma, A.G.J., H.J.W. de Baar, R.F. van Nolting and A.J. Bennekom. - 1991. Metal enrichment experiments in the WeddellScotia seas: effects of iron and manganese on various plankton communities. Limnol. Oceanogr., 36: 1865-1878.

Buscail, R., R. Pocklington, R. Daumas and L. Guidi. - 1990. Fluxes and budget of organic matter in the benthic boundary layer over the northwestern Mediterranean margin. Cont. Shelf Res., 10: 1089-1122.

Canals, M. and E. Ballesteros. - 1997. Production of carbonate particles by phytobenthic communities on the Mallorca-Menorca shelf, northwestern Mediterranean Sea. Deep-Sea Res. II, 44: 611-629.

Conan, P., M. Leveau and P. Raimbault. - 1996. EUROMARGENB : production primaire et flux des élements. In: M. Canals, J.L Casamor, I. Cacho, A.M Calafat and A. Monaco (eds.). EUROMARGE-NB Final Report, MAST II Programme, EU; Vol. IIIA, contr. n. 6, 9 pp.

Courp, T. and A. Monaco. - 1990. Sediment dispersal and accumulation on the continental margin of the Gulf of Lions: sedimentary budget. Cont. Shelf Res., 10: 1063-1087.

Cushing, D.H. - 1992. The loss of diatoms in the spring bloom. Philos. Trans. R. Soc. London Ser. B, 335: 237-246.

Danovaro, R., N. Della Croce, A. Eleftheriou, M. Fabiano, N. Papadopoulou, C. Smith and A. Tselepides. - 1995. Meiofauna of the deep eastern Mediterranean Sea: distribution and abundance in relation to bacterial biomass, organic matter composition and other environmental factors. Prog. Oceanogr., 36: 329-341

De Bovée, F., L. Guidi and J. Soyer. - 1990. Quantitative distribution of deep-sea meiobenthos in the northwestern Mediterranean (Gulf of Lions). Cont. Shelf Res., 10: 1123-1145.

De Jonge, V.N. and L.A. Bouwman. - 1977. A simple density separation technique for quantitative isolation of meiobenthos using the silica Ludox-TM. Mar. Biol., 42: 143-148.

Dinet, A., L. Laubier, J. Soyer and P. Vittiello. - 1973. Résultats biologiques de la campagne Polyméde. II Le méiobenthos abyssal. Rapp. Procés-Verb. Reun. Comm. Inter. Exp. Sci. Mer Méditerranée, Monaco, 21: 701-704.

Dinet, A. and A. Khripounoff. - 1982. Rapports quantitatifs entre le meiobenthos et la matière organique sédimentaire en zone abyssale. Colloques Intern. CNRS, 293: 319-324.

Dinet, A., P. Albert, J.-M. Amouroux, F. De Bovée, A. Grémare and G. Vétion. - 1996. Benthos distribution at the northwestern mediterranean continental margin: the EUROMARGE-NB survey (1993-1995. In: M. Canals, J.L Casamor, I. Cacho, A.M Calafat and A. Monaco (eds.). EUROMARGE-NB Final Report, MAST II Programme, EU; Vol. IIIB, contr. n. 35, 12 pp.

Estrada, M. - 1985. Deep phytoplankton and chlorophyll maxima in the Western Mediterranean. In: M. Moraitou-Apostolopoulou, V. Kiortsis (eds.), Mediterranean marine ecosystems, pp. 247-
277. Plenum Press, N.Y and London

Estrada, M. and R. Margalef. - 1988. Supply of nutrients to the mediterranean photic zone along a persistent front. Oceanol Acta $N^{\circ} S P, 133-142$.

Estrada, M., F. Vives and M. Alcaraz. - 1989. Vida y produccion en el mar abierto. In: R. Margalef (ed.), El Mediterraneo occidental, pp. 150-199. Editorial Omega, Barcelona.

Font, J., J. Salat and J. Tintoré. - 1988. Permanent features of the circulation in the Catalan Sea. Oceanol. Acta $N^{\circ} S P, 51-57$.

Gieskes, W.W.C. and G.W. Kraay. - 1983. Unknown chlorophyll $a$ derivatives in the North Sea and tropical Atlantic Ocean revealed by HPLC analysis. Limnol. Oceanogr., 28: 757-766.

Got, H. and J. C. Aloisi. - 1990. The Holocene sedimentation on the Gulf of Lions margin: a quantitative approach. Cont. Shelf Res. 10: $841-855$

Grehan, A. and B.F. Keegan. - 1996. The analysis of sediment physical characteristics by Sediment Profile Imagery (SPI). In: M. Canals, J.L Casamor, I. Cacho, A.M Calafat and A. Monaco (eds.). EUROMARGE-NB Final Report, MAST II Programme, EU; Vol. IIIB, contr. n. 36, 35 pp.

Guillard, R. and J.H Ryther. - 1962. Studies on marine planktonic diatoms. I. Cyclotella nana (Hustedt) and Detonula confervacea (Cleve) Gran. Can. J. Microbiol. 8: 229-239.

Heussner, S., R.D. Cherry and M. Heyraud. $-1990 .{ }^{210} \mathrm{Po},{ }^{210} \mathrm{~Pb}$ in sediment trap particles on a Mediterranean continental margin. Cont. Shelf Res., 10: 989-1004.

Klein, B. and C. Riaux-Gobin. - 1991. Algal pigment diversity in coastal sediments from Kerguelen (sub-Antarctic Islands) reflecting local dominance of green algae, euglenoids and diatoms. Polar Biol., 11: 439-448.

Lampitt, R.S. - 1985. Evidence for the seasonal deposition of detritus to the deep-sea floor and its subsequent resuspension. DeepSea Res., 32: 885-897.

Lochte, K. and C.M. Turley. - 1988. Bacteria and cyanobacteria associated with phytodetritus in the deep sea. Nature, 333: 67-69.

Margalef, R. - 1985. Environmental control of the mesoscale distribution of primary producers and its bearing to primary production in the western Mediterranean. In: M. Moraitou-Apostolopoulou, V. Kiortsis (eds.): Mediterranean marine ecosystems. pp. 213-229. Plenum Press, N.Y and London.

Masó, M. and C. M. Duarte. - 1989. The spatial and temporal structure of hydrographic and phytoplankton biomass heterogeneity along the Catalan coast (NW Mediterranean). J. Mar. Res., 47: 813-827.

Monaco, A., T. Courp, S. Heussner, J. Carbonne, S.W. Fowler and B. Deniaux. - 1990. Seasonality and composition of particulate fluxes during ECOMARGE-I, western Gulf of Lions. Cont. Shelf Res., 10: 959-987.

McIntire, A.D. - 1969. Ecology of marine meiobenthos. Biol. Revue, 44: 245-290.

Neveux, J. and F. Lantoine. - 1993. Spectrofluorometric assay of chlorophylls and phaeopigments using the least squares approximation technique. Deep-Sea Res., 40: 1747-1765.

Pfannkuche, O., A. Boetius, K. Lochte, U. Lundgreen and H. Thiel. - 1999. Responses of deep-sea benthos to sedimentation patterns in the North-East Atlantic in 1992. Deep-Sea Res., I, 46: 573-596.

Pfannkuche, O., S. Sommer and A. Kähler. - 2000. Coupling between phytodetritus deposition and small-sized benthic biota in the deep Arabian Sea: analyses of biogenic sediment compounds. Deep-Sea Res., I, 47: 2805-2833.

Puig, P. and A. Palanques. - 1998. Temporal variability and composition of settling fluxes on the Barcelona continental margin. J. M. Res., 56: 639-654.

Riaux-Gobin, C. and C. Descolas-Gros. - 1992. Assemblage de microphytes enkystés à la surface de sédiments profonds, sur le talus continental du golfe du Lion. C.-R. Acad. Sci. Paris, 314: 545-552.

Riaux-Gobin, C., G. Dugué, G. Vétion and E. Maria. - 1996. Pigments chlorophylliens à l'interface eau/sédiment, relations avec le phytoplancton des masses d'eau sus-jacentes et tests de reviviscence. In: M. Canals, J.L Casamor, I. Cacho, A.M Calafat and A. Monaco (eds.). EUROMARGE-NB Final Report, MAST II Programme, EU; Vol. IIIB, contr. n. 34, 22 pp.

Riaux-Gobin, C., M.-J. Chrétiennot-Dinet and C. Descolas-Gros. 1995. Undamaged sedimented coccolithophorids in a deep environment (continental slope of the Gulf of Lions). Mar. Geol., 123: 239-252. 
Riaux-Gobin, C., P.E. Hargraves, J. Neveux, L. Oriol and G. Vétion. - 1997. Microphyte pigments and resting spores at the water-sediment interface in the Subantarctic deep sea (Indian sector of the Southern Ocean). Deep-Sea Res., 44: 1033-1051.

Rice, A.L.D. S.M. Billet, J.Fry, A.W.G. Johns, R.S. Lampitt, R.F.C. Mantoura and R.J. Morris. - 1986. Seasonal deposition of phytodetritus to the deep-sea floor. Proc. R. Soc. Edinb. Sect. $B, 88: 265-279$.

Rowan, K.S. - 1989. Photosynthetic pigments of algae. Cambridge University Press, Cambridge.

Sánchez-Cabeza, J.A., P. Masqué, A. Palanques and P. Puig. 1996. ${ }^{210} \mathrm{~Pb}$ fluxes to sediment traps from the Catalan Sea margin. In: M. Canals, J.L Casamor, I. Cacho, A.M Calafat and A. Monaco (eds.). EUROMARGE-NB Final Report, MAST II Programme, EU; Vol. IIIB, contr. n. 62, 6pp.

Santos, V., D.S.M. Billet, A.L. Rice and G.A. Wolff. - 1994.
Organic matter in deep-sea sediments from the Porcupine Abyssal Plain in the north-east Atlantic Ocean. I-Lipids. DeepSea Res., 41: 787-819.

Thiel, H., O. Pfannkuche, G. Scriever, K. Lochte, A.J. Gooday, C. Hemleben, R.F.C. Mantoura, C.M. Turley, J.W. Patching and F. Riemann. - 1988-1989. Phytodetritus on the deep-sea floor in a central oceanic region of the Northest Atlantic. Biol. Oceanogr., 6: 203-239.

Thomas, A.J. - 1997. Input of artificial radionuclides to the Gulf of Lions and tracing the Rhône influence in marine surface sediments. Deep-Sea Res. II, 44: 577-595.

Zuo, Z., D. Eisma, R. Gieles and J. Beks. - 1997. Accumulation rates and sedimentation deposition in the northwestern Mediterranean. Deep-Sea Res. II, 44: 597-609.

Scient. ed.: A. Palanques 